\title{
Single-dose Pharmacokinetics of Recombinant Human Erythropoietin in Patients with Various Degrees of Renal Failure
}

\author{
J. Kindler ${ }^{1}$, K.-U. Eckardt ${ }^{3}$, B. Ehmer ${ }^{2}$, K. Jandeleit ${ }^{1}$, A. Kurtz ${ }^{3}$, A. Schreiber ${ }^{3}$, P. Scigalla ${ }^{2}$ and \\ H.-G. Sieberth ${ }^{1}$ \\ 'Department of Internal Medicine II, RWTH Aachen, ${ }^{2}$ Boehringer Mannheim GmbH, FRG, and ${ }^{3}$ Institute of Physiology, \\ Zürich, Switzerland
}

\begin{abstract}
The pharmacokinetic profile of recombinant human erythropoietin ( $\mathrm{rHuEpo}$ ) was studied after a single intravenous dose of $150 \mathrm{U} / \mathrm{kg}$ in ten patients with various degrees of renal function: group I, creatinine clearance $>80 \mathrm{ml} / \mathrm{min}, n=2$; group II, creatinine clearance $10-50 \mathrm{ml} / \mathrm{min}, n=6$; group III, creatinine clearance $<3 \mathrm{ml} / \mathrm{min}$ (patients undergoing haemodialysis) $n=2$. Erythropoietin concentrations in serum and urine samples obtained over $48 \mathrm{~h}$ were measured by RIA. rHuEpo was cleared from circulation in an exponential fashion, the half-life ranged from 6.5 to $12.7 \mathrm{~h}$ (mean $9.03 \mathrm{~h}$ ) and was not different between the groups. The apparent volume of distribution varied from 0.041 to $0.0991 / \mathrm{kg}$ (mean $0.070 \mathrm{l} / \mathrm{kg}$ ) this corresponds to 1.5 times the plasma volume and was unrelated to kidney function. Renal clearance (groups I, II) accounted for less than $3 \%$ of total body clearance, both parameters were unaffected by decreasing renal function.

These results indicate that, in accordance with animal data, the elimination of rHuEpo occurs mainly through non-renal mechanisms.
\end{abstract}

Key words: Recombinant human erythropoietin; Pharmacokinetics; Renal function

Correspondence and offprint requests 10: Professor Dr J. Kindler, Department of Internal Medicine II, RWTH Aachen, Pauwelsstraße, D-5100 Aachen, FRG.

\section{Introduction}

Initial clinical experience with the use of recombinant human erythropoietin ( $\mathrm{rHuEpo}$ ) for the treatment of the anaemia of end-stage renal disease has been very encouraging, with correction of the anaemia in nearly all cases and improvement of the well-being of patients on dialysis $[1,2]$. However, relatively little is known about the pharmacokinetic behaviour of erythropoietin; this is due to a previous lack of sensitive and specific assay techniques for the hormone. In recent preliminary pharmacokinetic studies the plasma half-life of rHuEpo in humans ranged between $4 \mathrm{~h}$ and $12 \mathrm{~h}[3-6]$. The objective of the present study was to determine the effect of decreasing renal function on the pharmacokinetic profile of the hormone after a single intravenous dose.

\section{Patients and Methods}

Ten subjects aged 29-65 years, with a bodyweight between 61 and $115 \mathrm{~kg}$, were divided into three groups according to their renal function: group I, creatinine clearance $>80 \mathrm{ml} / \mathrm{min}$ per $1.73 \mathrm{~m}^{2}, n=2$; group II, creatinine clearance $10-50 \mathrm{ml} / \mathrm{min}$ per $1.73 \mathrm{~m}^{2}, n=6$; group III, creatinine clearance $<3 \mathrm{ml} / \mathrm{min}$ per $1.73 \mathrm{~m}^{2}$ (patients undergoing haemodialysis), $n=2$.

The objectives and implications of the study were explained and signed informed consent was obtained from each subject, as specified in the declaration of Helsinki (Tokyo revision 1975). Table I demonstrates patient characteristics. Six of the eight patients with 
Table 1. Patient demographic data

\begin{tabular}{rlllll}
\hline Patient & Sex & $\begin{array}{l}\text { Underlying } \\
\text { disease }\end{array}$ & $\begin{array}{l}\text { Creatinine } \\
\text { clearance } \\
\left(\mathrm{ml} / \mathrm{min} / 1.73 \mathrm{~m}^{2}\right)\end{array}$ & $\begin{array}{l}\text { Haematocrit } \\
\text { (Vol \%) }\end{array}$ & $\begin{array}{l}\text { Erythropoietin } \\
(\mathrm{mU} / \mathrm{ml})\end{array}$ \\
\hline 1 & $\mathrm{~m}$ & Chronic bronchitis & 102 & 40 & 19 \\
2 & $\mathrm{~m}$ & Vasovagal syncope & 100 & 44 & 22 \\
3 & $\mathrm{~m}$ & Chronic glomerulonephritis & 50 & 48 & 13 \\
4 & $\mathrm{~m}$ & Chronic glomerulonephritis & 50 & 42 & 13 \\
5 & $\mathrm{~m}$ & Chronic glomerulonephritis & 20 & 33 & 13 \\
6 & $\mathrm{w}$ & Chronic glomerulonephritis & 20 & -10 & 17 \\
7 & $\mathrm{~m}$ & Chronic pyelonephritis & 7.9 & 40 & 17 \\
8 & $\mathrm{~m}$ & Chronic glomerulonephritis & 7.9 & 30 & 16 \\
9 & $\mathrm{w}$ & Chronic pyelonephritis & 0 & 20 & 15 \\
\hline 10 & $\mathrm{~m}$ & Chronic glomerulonephritis & 0 & 24 & \\
\hline
\end{tabular}

chronic renal failure had chronic glomerulonephritis, four of the ten patients suffered from anaemia with a haematocrit less than $33 \%$. In all subjects the serum concentrations of erythropoietin were in the normal range $(10-25 \mathrm{mU} / \mathrm{ml})$. Especially in the two dialysis patients, the serum hormone concentrations were inappropriately low for the degree of anaemia.

The recombinant human erythropoietin was dissolved in $2 \mathrm{ml}$ of sterile distilled water and subsequently administered as a single intravenous bolus injection to each patient in a dosage ranging from 130 to $152 \mathrm{U} / \mathrm{kg}$ bodyweight. Venous blood samples $(1 \mathrm{ml})$ for assay of erythropoietin were obtained by venepuncture immediately before and $0.25,0.5,0.75,1,2,3,4,5,6,8,10,12,18,24$, 36,40 and $48 \mathrm{~h}$ after administration. Blood specimens were collected in vacutainers and centrifuged, and the serum separated and frozen at $-20^{\circ} \mathrm{C}$ until analysis. Urine was collected during the 48-h period in all subjects except the two dialysis patients. The total volume of urine voided during the collection period was measured and mixed thoroughly. A $10-\mathrm{ml}$ aliquot from each urine collection was removed and stored frozen at $-20^{\circ} \mathrm{C}$ until analysis.

Erythropoietin was estimated in serum and urine samples as described previously [7], using a radioimmunoassay based on rHuEpo as tracer and immunogen. The lower detection limit of the assay is $5 \mathrm{mU} \mathrm{Epo/ml,}$ the interassay coefficient of variation is $6.7 \%$ (51 estimations of a sample containing $44.2 \pm 3.0 \mathrm{mU}$ Epo/ml; mean $\pm \mathrm{SD}$ ). To eliminate differences in dosages the serum concentrations were corrected to a dosage of $150 \mathrm{U} / \mathrm{kg}$ bodyweight. Model-independent pharmacokinetic parameters, including time-independent peak values were obtained directly from the data. The further parameters were calculated according to standard pharmacokinetic equations [8], for example the areas under the concentration-time curve (AUC) were calculated by the trapezoidal rule and the elimination rate constant $\mathrm{k}$ was obtained from the slope of the approximately log-linear part of the concentration-time curve by linear regression. The data were best fitted by a two-compartment open model. Group data were expressed as $x \pm S E M$.

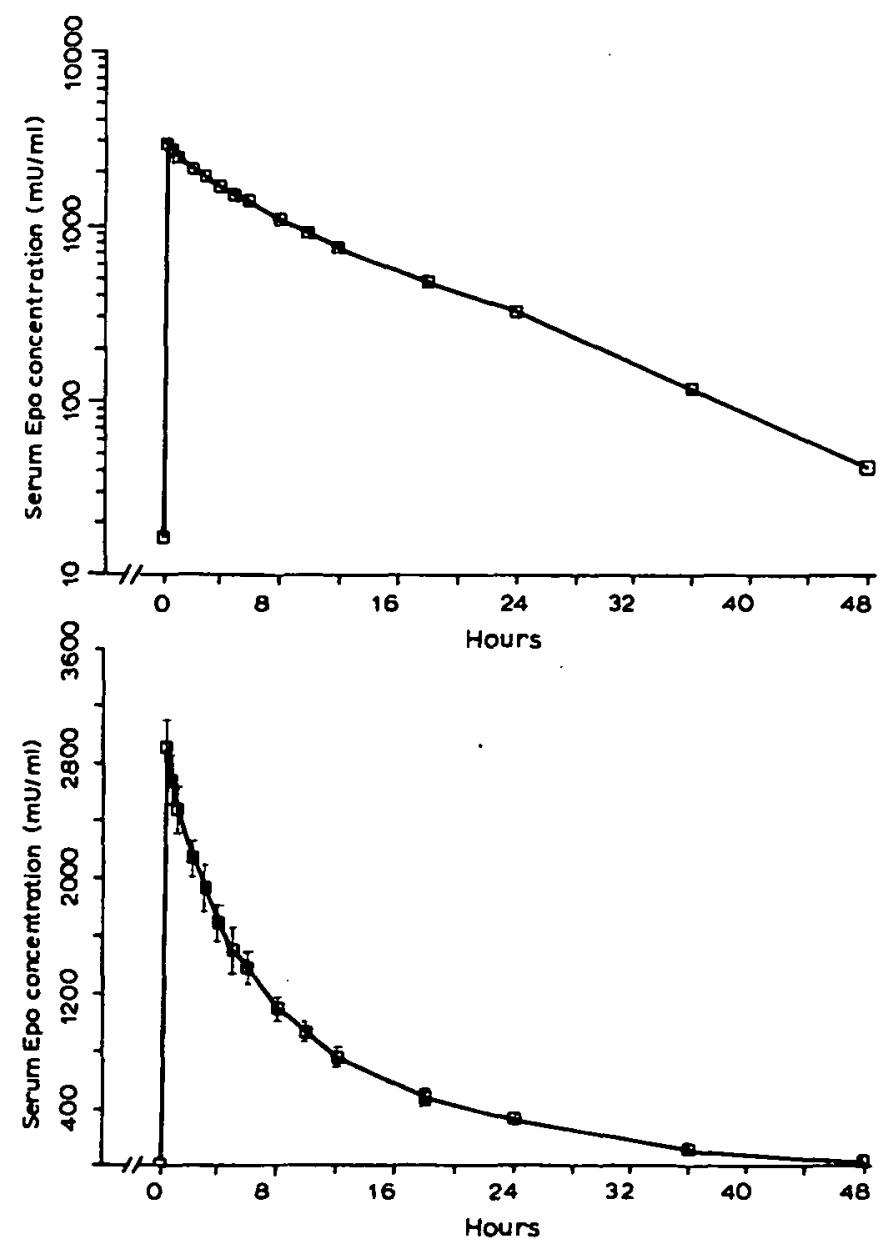

Fig. 1. Serum concentration-time profile after a single intravenous application of rHuEpo in a dosage of $150 \mathrm{U} / \mathrm{kg}$ body weight to ten patients with various degress of renal function. (Upper panel: semilogarithmic plot of serum concentration.) 
Table 2. Pharmacokinetic parameters of recombinant human erythropoietin (rHuEpo) in patients with various degrees of renal function

\begin{tabular}{|c|c|c|c|c|c|c|c|}
\hline $\begin{array}{l}\text { Patient } \\
\text { Group }\end{array}$ & $\begin{array}{l}\mathrm{AUC}_{0-48} \\
(\mathrm{mU} / \mathrm{h} / \mathrm{ml})\end{array}$ & $\begin{array}{l}t_{128}^{2 B} \\
(h)\end{array}$ & $\begin{array}{l}V_{x} \\
(1 / k g)\end{array}$ & $\begin{array}{l}t_{12 x} \\
\text { (h) }\end{array}$ & $\begin{array}{l}\mathrm{Cl} \\
(\mathrm{ml} / \mathrm{min} / \mathrm{kg})\end{array}$ & $\mathrm{Cl}_{(\mathrm{ml} / \mathrm{min} / \mathrm{kg})}$ & $\begin{array}{l}\mathrm{Cl}_{k} \text { in } \\
\text { of } \mathrm{Cl}\end{array}$ \\
\hline \multicolumn{8}{|c|}{$\begin{array}{l}\text { I } \\
\text { Creatinine clearance } \\
>80 \mathrm{ml} / \mathrm{min}\end{array}$} \\
\hline $\begin{array}{l}\text { Mean } \\
\text { SEM }\end{array}$ & $\begin{array}{r}20539.4 \\
290.3\end{array}$ & $\begin{array}{l}8.52 \\
1.02\end{array}$ & $\begin{array}{l}0.088 \\
0.011\end{array}$ & $\begin{array}{l}2.36 \\
0.84\end{array}$ & $\begin{array}{l}0.1197 \\
0.0005\end{array}$ & $\begin{array}{l}0.0011 \\
0.0002\end{array}$ & $\begin{array}{l}0.92 \\
0.17\end{array}$ \\
\hline \multicolumn{8}{|c|}{$\begin{array}{l}\text { II } \\
\text { Creatinine clearance } \\
\qquad 10-50 \mathrm{ml} / \mathrm{min}\end{array}$} \\
\hline $\begin{array}{l}\text { Mean } \\
\text { SEM }\end{array}$ & $\begin{array}{r}29497.8 \\
2219.7\end{array}$ & $\begin{array}{l}8.76 \\
0.89\end{array}$ & $\begin{array}{l}0.065 \\
0.008\end{array}$ & $\begin{array}{l}1.94 \\
0.59\end{array}$ & $\begin{array}{l}0.0855 \\
0.0069\end{array}$ & $\begin{array}{l}0.0019 \\
0.0052\end{array}$ & $\begin{array}{l}2.24 \\
0.32\end{array}$ \\
\hline \multicolumn{8}{|c|}{$\begin{array}{l}\text { III } \\
\text { Creatinine clearance } \\
\quad<3 \mathrm{ml} / \mathrm{min}\end{array}$} \\
\hline $\begin{array}{l}\text { Mean } \\
\text { SEM }\end{array}$ & $\begin{array}{r}31375.9 \\
6550.7\end{array}$ & $\begin{array}{r}10.37 \\
2.35\end{array}$ & $\begin{array}{l}0.069 \\
0.0005\end{array}$ & $\begin{array}{l}1.46 \\
0.16\end{array}$ & $\begin{array}{l}0.0803 \\
0.0190\end{array}$ & - & $\overline{-}$ \\
\hline $\begin{array}{l}\text { Total mean } \\
\text { SEM }\end{array}$ & $\begin{array}{r}28081.7 \\
2058.2\end{array}$ & $\begin{array}{l}9.03 \\
0.68\end{array}$ & $\begin{array}{l}0.070 \\
0.006\end{array}$ & $\begin{array}{l}1.93 \\
0.36\end{array}$ & $\begin{array}{l}0.0913 \\
0.0071\end{array}$ & $\begin{array}{l}0.0017 \\
0.0002\end{array}$ & $\begin{array}{l}1.86 \\
0.33\end{array}$ \\
\hline
\end{tabular}

AUC $=$ area under serum concentration-time curve

$t_{1,3}=$ terminal half-life

$t_{12 a}=$ half-life of the distribution phase

$\mathrm{V}_{\mathrm{z}}=$ apparent volume of distribution

$\mathrm{Cl}=$ total body clearance

$\mathrm{Cl}_{\mathrm{R}}=$ renal clearance

\section{Results}

Figure 1 demonstrates the 48 -h profiles of average serum erythropoietin concentrations for all ten patients after the single intravenous administration of the hormone. The time-independent peak values ranged between 1.781 and $3.647 \mathrm{mU} / \mathrm{ml}$ (mean $2910.5 \mathrm{mU} / \mathrm{ml}$ ) and did not differ between groups. Recombinant human erythropoietin was cleared from circulation in a complex manner. Using the semilogarithmic plot of serum concentration (upper panel of Fig. 1), a biexponential decay curve was obtained. After an initial faster decline corresponding to the distribution phase, a slower decrease of serum erythropoietin concentration can be observed, which represents the elimination of the hormone. When the early phase of the disappearance curve (reflecting mainly distribution and elimination effects) is excluded, the apparent serum halflife of rHuEpo averaged $9.03 \mathrm{~h}$ (range 6.5-12.7 h) and was unrelated to renal function (Table 2.)

Figure 2 shows the comparative time courses of mean serum concentrations of erythropoietin after a bolus injection of $150 \mathrm{U} / \mathrm{kg}$ bodyweight in the three patient groups. The areas under the serum Epo concentrationtime curves $\left(\mathrm{AUC}_{0-48 \mathrm{k}}\right)$ of all patients varied from 20219 to $37926 \mathrm{mU} / \mathrm{h}$ per $\mathrm{ml}$ (mean 28081.7) and were unrelated to kidney function.

Pooling the data from all subjects, the apparent volume of distribution of the injected hormone averaged $0.070 \mathrm{l} / \mathrm{kg}$ (range 0.041-0.099), this corresponds to 1.5 times of the

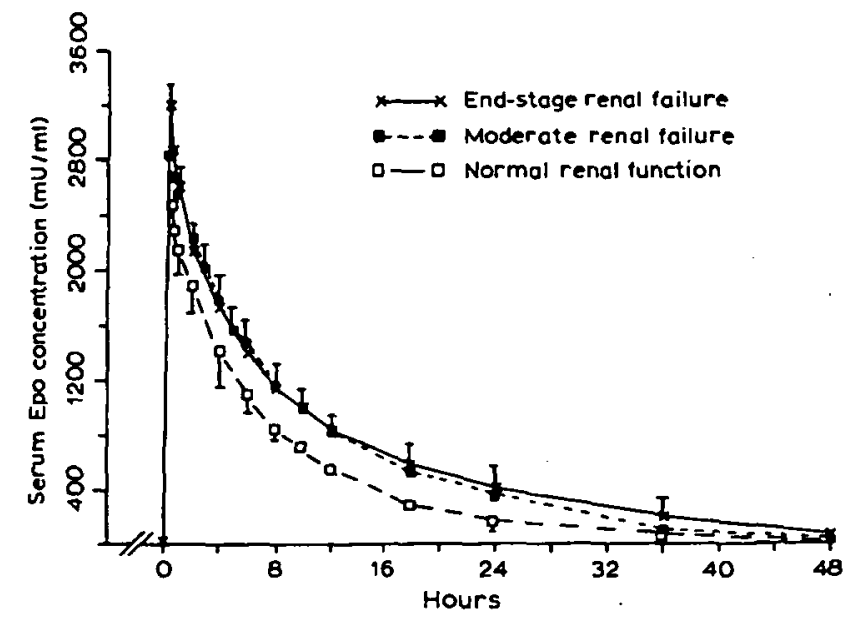

Fig. 2. Mean serum concentrations of rHuEpo after a single intravenous administration of $150 \mathrm{U} / \mathrm{kg}$ bodyweight to patients with various degrees of renal function.

plasma volume. The mean half-life of the distribution phase $\left(t_{1 / 2 a}\right)$ was $1.93 \mathrm{~h}$ and did not correlate to kidney function.

The average total body clearance of rHuEpo in the whole study group was $0.0913 \mathrm{ml} / \mathrm{min}$ per $\mathrm{kg}$ (range 0.0613-0.1203) and did not show any correlation with the creatinine clearance. No significant difference between the groups could be detected for renal clearance of rHuEpo, which was found to be less than $3 \%$ of total body clearance (mean $1.86 \%$ of total clearance). 


\section{Discussion}

The majority of previous studies on the pharmacokinetic profile of erythropoietin has been carried out with impure preparations using insensitive and highly variable bioassays for the determination of plasma disappearance of erythropoietin in different animal species and in humans [9-12]. In recent years the development of sensitive radioimmunoassays for erythropoietin has provided an important tool for studies on the pharmacokinetic behav. iour of the hormone [7]. Our results confirm previous investigations [5,9-11,13,14], that erythropoietin administered by pulse injection is cleared from circulation in a multiexponential fashion. After exclusion of the initial distribution phase of the disappearance curve an approximate monoexponential decay curve of rHuEpo was obtained. The serum half-life of the injected hormone averaged $9.03 \mathrm{~h}$ and was unffected by renal function. Corresponding data were reported in normal healthy volunteers [6] and in patients on maintenance haemodialysis $[4,5]$. In these studies mean half-life of rHuEpo after the first injection ranged between $8.6 \mathrm{~h}$ and $12 \mathrm{~h}$ and was unrelated to the dose of the hormone. A significant decrease in half-life could be observed on continued treatment with rHuEpo $[4,5]$. Animal data with ${ }^{35}$ S-labelled and biologically active recombinant erythropoietin did not show any difference in the half-life of the hormone in normal and uraemic rats with $12.8 \mathrm{~h}$ and $11.5 \mathrm{~h}$ respectively. However, in a pharmacokinetic study in the rat with pure human erythropoietin labelled with ${ }^{125} \mathrm{I}$, the plasma half-life of the hormone was significantly prolonged from $3.5 \mathrm{~h}$ in normal rats to $4.4 \mathrm{~h}$ in animals with ligated renal pedicles under steady-state conditions [13]. Similar data were obtained in dogs by use of ${ }^{125}$ I-labelled purified recombinant erythropoietin ( $r$ Epo) [14]. The mean elimination half-life for ${ }^{125} \mathrm{I}-\mathrm{rEpo}$ in intact dogs $(9.0 \pm 0.6 \mathrm{~h})$ and anephric dogs $(13.8 \pm 1.4 \mathrm{~h})$ was significantly different $(P<0.05)$. Previous observations together with the results of the present investigation suggest that peripheral erythropoietin elimination occurs mainly through non-renal mechanisms.

In patients with normal and impaired renal function the apparant volume of distribution of the injected hormone approximated to 1.5 times the plasma volume. This finding indicates that $r$ HuEpo penetrates the extracellular space, even if the distribution volume of the hormone was found to be smaller than the latter. Confirmation of the substantial extravascular distribution space was also obtained in different animal species and in humans $[6,9-12,13,14]$. The total body clearance values of $\mathrm{rHuEpo}$ obtained in this study were consistently low $(0.0613-0.1203 \mathrm{ml} / \mathrm{min}$ per $\mathrm{kg})$ and were not influenced by decreasing renal function. In contrast, Fu et al. reported a $30 \%$ decrease of elimination clearance of ${ }^{125} \mathrm{I}$-rEpo after bilateral nephrectomy when compared with that of the intact dog. Thus species differ- ences in the pharmacokinetic profile of erythropoietin must be considered likely. In comparison with the protein hormones insulin, glucagon or prolactin [16-18], the metabolic clearance rate of erythropoietin in rats was found to be considerably less but was similar to the metabolic clearane rate of glycoprotein hormones as homologous luteinizing and follicle stimulating hormone [13].

The renal handling of erythropoietin is still unclear. Although kidney homogenates degraded ${ }^{125} \mathrm{I}-\mathrm{Epo}$ in vitro [13], the physicochemical characteristics of this glycoprotein hormone probably impede its degradation and elimination by the kidneys. In the present study, renal clearance of rHuEpo accounted for less than $3 \%$ of total body clearance and did not depend on renal function. These data are in close agreement with previous reports suggesting that in rats, dogs and humans the urinary excretion contributes only $4 \%-10 \%$ of the overall elimination rate of erythropoietin [11-13]. In view of this finding it seems likely that peripheral erythropoietin disposal occurs mainly through the liver and possiby through erythropoietic tissue.

In summary, this study demonstrates, that the peripheral metabolism of rHuEpo is remarkably sluggish and depends mainly on extrarenal elimination mechanisms.

\section{References}

1. Winearls CG, Oliver DO, Pippard MJ, Reid C, Dowing MR, Cotes PM. Effect of human erythropoietin derived from recombinant DNA on the anaemia of patients maintained by chronic haemodialysis. Lancet 1986; 2: 1175-1178

2. Eschbach JW, Egrie JC, Downing MR, Browne JK, Adamson JW. Correction of the anemia of end-stage renal disease with recombinant human erythropoietin: results of a Phase I and II clinical trial. $N$ Eng/J Med 1987; 316: 73-78

3. Winearls CG, Cotes PM, Pippard M, Reid C, Oliver DO. Correction of anaemia in haemodialysis patients with recombinant erythropoietin - follow up and results of pharmacokinetics, ferrokinetics and bone marrow culture studies. Xth International Cangress of Nephrology, London 26-32 July 1987, Abstracts, p. 183

4. Muirhead N, Keown PA, Slaugther D et al. Recombinant human erythropoietin in the anaemia of chronic renal failure: a pharmacokinetic study. Nephrol Dial Transplant 1988; 3: 499

5. Egrie JC, Eschbach JW, McGuire T, Adamson JW. Pharmacokinetics of recombinant human erythropoietin ( $r$ HuEpo) administered to hemodialysis (HD). Kidney Int 1988; 33: 262

6. Urabe A, Tabaku F, Mizoguchi $H$ et al. Effect of recombinant human erythropoietin on the anemia of chronic renal failure. Int $J$ Cell Cloning 1988; 6: 179-191

7. Eckardt K-U, Kurtz A, Hirth P, Scigalla P, Wieczorek L. Bauer C. Evaluation of the stability of human erythropoietin in samples for radioimmunoassay. Klin Wochenschr 1988; 66: 241-245

8. Committee for pharmacokinetic nomenclature of the American College of Clinical Pharmacology, Philadelphia, Pennsylvania. Manual of symbols, equations and definitions in pharmacokinetic. $J$ Clin Pharmacol 1982; 22: ??

9. Reisman KR, Dietrich DA, Ito K, Schmaus JW. Influence of disappearance rate and distribution space on plasma concentration of erythropoietin in normal rats. J Clin Invest 1965; 65: 967-975

10. Roh BL, Paulo LG, Thompson J, Fisher JW. Plasma disappearance of ${ }^{125}$ I-labeled erythropoietin in anesthetized rabbits. Proc Soc Exp Biol Med 1972; 141: 268-270

11. Weintraub AH, Gordon AS, Bucker EL, Camiscoli JF, Contrera 
JF. Plasma and renal clearance of exogenous erythropoietin in the dog. Am J Physiol 1964; 207: 523-529

12. Rosse WF, Waldmann TA. The metabolism of erythropoietin in patients with anemia due to deficient erythropoiesis. J Clin Inves 1964: 43: 1348-1354

13. Emmanouel DS, Goldwasser E, Katz AJ. Metabolism of pure human erythropoietin in the rat. Am J Physiol 1984; 247: F168-F176

14. Fu J-S, Lertora JJL, Brookins J, Rice JC, Fisher JW. Pharmacokinetics of erythropoietin in intact and anephric dogs. $J$ Lab Clin Med 1988; $111: 669-676$

15. Scigalla P. Hoelk G. Pahlke W. Pharmacokinetics of recombinant erythropoietin (rEpo) in normal and uraemic rats. Nephrol Dial Transplant 1987: 2: 389

16. Emmanouel DS, Fang VS. Katz J. Prolactin metabolism in the rat: role of the kidney in degradation of the hormone. (Renal Fluid Electrolyte Physiol 9) Am J Phirsiol 1981; 240: F437-F445

17. Emmanouel DS, Jaspan JB, Rubenstein AH, Huen AH-J, Fink E. Katz AJ. Glucagon metabolism in the rat. Contribution of the kidney to the matabolic clearance rate of the hormone. $J$ Clin Invest 1978; 62: 6-13

18. Katz AJ, Rubenstein AH. Metabolism of proinsulin, insulin and C-peptide in the rat. J Clin Invest 1973; 52: 1113-1121

Received for publication 18.1 .89

Accepted 24.1.89 